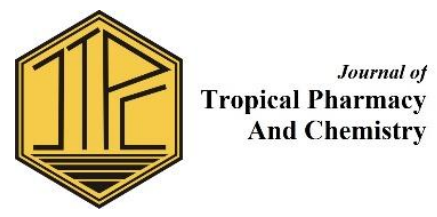

\title{
MECHANISM OF VASORELAXATION INDUCED BY Coptosapelta flavescens STEMS EXTRACT IN RAT THORACIC AORTA
}

\author{
Sjarif Ismail $^{1,2} *$, Khemasili Kosala ${ }^{2}$, Ika Fikriah ${ }^{2}$, Agustina Rahayu Magdaleni $^{3}$ \\ ${ }^{1}$ Research Center on Drugs and Public Health Mulawarman University, Samarinda \\ ${ }^{2}$ Pharmacology Laboratory, Faculty of Medicine Mulawarman University, Samarinda \\ ${ }^{3}$ Physiology Laboratory, Faculty of Medicine Mulawarman University, Samarinda \\ *Corresponding Author email: ismail@fk.unmul.ac.id and ismail8997@yahoo.com
}

\begin{abstract}
Coptosapelta flavescens Korth. is a liana plant from the Rubiaceae family. In East Kalimantan, it is also known as "Akar Tambolekar" or "Merung", it is called "akar" or root as its trunk spreads like a root. The plant's stems are used by ethnic Dayak in East Kalimantan to overcome high blood pressure and it has been proven to induce vasorelaxation on blood vessels, but the its action mechanism in the endothelial or vascular smooth muscle cells (VSMC) are unknown. Vasorelaxation on the blood vessels could be mediated by endothelial or by the VSMC. This research aims to study in vitro which of them is the mechanism of action of Coptosapelta flavescens Stems (CFS) extract. CFS were taken from the secondary forest in Paser Regency, East Kalimantan Province. Its simplicia were macerated with methanol solvent for three days and twice repeated. Vasorelaxation activity of the blood vessels was tested with rats' isolated thoracic aorta with endothelial and with the endothelial removed (endothelium-denuded). Both aorta of $3 \mathrm{~mm}$ length were soaked into Krebs-Henselheit solution at $37^{\circ} \mathrm{C}, \mathrm{pH} 7.4$ and aerated with carbogen gas. After they have acclimatized, both aortas were contracted with phenylephrine solution, after reaching peak contraction and plateau, the solution of extract or its solvent (Control) was administered in cumulatively increasing doses. The results show that CFS extracts induce vasorelaxation both in the endothelial-intact aorta and in the endothelial-denuded aorta. At high concentrations, the vasorelaxation activity in the endothelial-intact aorta was weaker than that on endothelial-denuded aorta. This study proves that action mechanism of blood vessels' vasorelaxation induced by the methanol extract of CFS were more dominantly mediated by the blood vessels smooth muscle; and at high concentrations the endothelial actually weakened the VSMC vasorelaxation activity. Further study is necessary on the mechanism of action vasorelaxation through the modulation of intracellular or extracellular calcium ion channels of VSMC
\end{abstract}

Keywords: Coptosapelta flavescens, vasorelaxation, extract, aorta, in vitro

Submitted on: 8 November 2017 Accepted on: 21 December 2017

DOI: https://doi.org/10.25026/jtpc.v4i2.146

\section{INTRODUCTION}

The prevalence of hypertension in the world wide is estimated to reach one billion people and causing 7.1 million deaths every year [1]. High blood pressure can increase the incidence of cerebrovascular disease by $62 \%$ and coronary heart disease by $49 \%$ [2].
Hypertension treatment has to be for long term so that the blood pressure can be controlled and the incidence rate of cerebrovascular disease and coronary heart disease can be reduced. Currently, antihypertensive drugs are still limited and mostly imported. Research to find new raw materials for hypertensive drugs 
is therefore urgently needed due to its economic value. Antihypertensive raw materials can come from the plants as they are one of the sources of drugs' raw materials now and in the future. One of the potential plants to be studied is Coptosapelta flavescens.

Coptosapelta flavescens Korth. or its synonym Thysanospernum Champ ex Benth is a liana plant from the Rubiaceae family, it is abundantly found in East Kalimantan and grows wild in the secondary forest. Dayak Paser ethnic group in East Kalimantan refers to it as Tambolekar Roots or Merung, and Banjar ethnicity refers to it as Manuran Roots. It is called 'root' as its stem spreads like a root. Ethnobotanical exploration results shows that it is used as herbs to cure high blood pressure, cough and shortness of breath [3] and as aphrodisiac [4]. Research results have shown that it contains 1-hydroxy-2hydroxymethylanthraquinone which exhibits antigiardial and antientamoebal activity on intestinal infections [5,6]. In other studies, anthraquinone derivatives in other plants have been shown to have vasorelaxation activity in blood vessels $[7,8]$.

The methanol extract of Coptosapelta flavescens Stems (CFS) in recent studies has been shown to induce vasorelaxation in rats' isolated aorta with endothelial [9], but whether the vasorelaxation mechanism is mediated by endothelial or not is still unknown and needs to be investigated further. It is to be determined if the action mechanism of vasorelaxation is mediated by endothelial or VSMC as hypertension drugs with blood vessels' vasorelaxation action mechanism on endothelial will not be effective on hypertension patients with endothelial dysfunction.

\section{METHOD}

\section{Materials and Tools}

Phenylephrine

(PE) and

Methacholine (META) from SigmaAldrich. Proanalyst chemicals such as calcium chloride, glucose, magnesium chloride, potassium chloride, potassium dihydrogen phosphate, sodium chloride, sodium bicarbonate, methanol, ethanol, DMSO from Merck.

Octal bridge amplifier and Power Lab/16SP digital recorder from AD instrument, isometric transducer 7004 from Ugo Basile. Vacuum rotavapour, $\mathrm{pH}$ meter, $10 \mathrm{ml}$ double jacket chamber, circulatory pump, micropipet and tips.

\section{Trial Animals and Ethical Approval}

Male Wistar rats, age 4-6 months, body weight 200-250 g, obtained from the Faculty of Medicine, University of Mulawarman, Samarinda, Indonesia. All research procedures used to test the animals had been approved by the Ethics Committee of the Faculty of Medicine, University of Mulawarman.

\section{Plants Collection and Making of Simplicia. \\ CFS was taken from the} secondary forest of Paser Regency, East Kalimantan Province. Identification of types was assisted by the taxonomists from the Mulawarman University's Faculty of Forestry. Herbaria was stored in the Laboratory of Faculty of Medicine with Specimen Voucher number CF 01/X/2017. CFS was washed with clean running water and cut transversely into small pieces and kept in a $60^{\circ} \mathrm{C}$ dryer cupboard for one week and the herbs were flipped over daily. CFS was finely ground and dried further until moisture content $<10 \%$. 


\section{Extraction}

CFS simplicia was extracted by maceration using methanol solvent at a ratio of 1: 4 for five days and remacerated twice. The extract was filtered and concentrated with a vacuum rotavapor at $50^{\circ} \mathrm{C}$. The concentrated extract is further dried by putting them into a vacuum container with blue silica gel and heated at $60^{\circ} \mathrm{C}$ oven for one week with the silica gel replaced daily with a new one until moisture content $<10 \%$.

\section{Preparation of Rats' Isolated Thoracic Aorta}

The male Wistar rat was killed off with an overdose of ketamine injections, then the aortic preparation was performed as described by Ismail et al. [10]. Abdomen and thorax were opened. Thoracic aorta was to the left of thoracic vertebra, free up the aorta using scissors from distal (at a junction with a. Renalis) to the aortic arcus carefully so that the endothelial is not damaged. The aortic organs were taken and put into cold Krebs-Henselheit solution $\left(4^{\circ} \mathrm{C}\right)$ with a composition of $(\mathrm{mM}): \mathrm{NaCl} 118.0 ; \mathrm{KCl}$ 4.7; $\mathrm{CaCl}_{2} 1.5 ; \mathrm{MgSO}_{4} 1.1 ; \mathrm{KH}_{2} \mathrm{PO}_{4} 1.2$; $\mathrm{NaHCO}_{3} \quad 25.0$ and glucose 10.0 and aerated with carbogen gas (a mixture of $\left.\mathrm{O}_{2} 95 \%+\mathrm{CO}_{2} 5 \%\right), \mathrm{pH}$ 7.4. The aorta was carefully cleared from any connective tissue to avoid damage to the endothelium, and cut transversely $3 \mathrm{~mm}$ in length to form a ring shape. The aortic ring was suspended in a $10 \mathrm{~mL}$ double jacket organ bath using two stainless steel wires with $2 \mathrm{~g}$ basal tone as described by Ismail and Yuniati [11]. One end of the wire was connected to an isometric transducer connected to AD Instrument digital recorder amplifier equipped with Program Chart version 5 and stored in the computer's hard disk. Equilibration was performed for 90 minutes with the KrebsHenselheit solution being replaced every
15 minutes with a new one at $\mathrm{pH} 7.4$ and temperature of $37^{\circ} \mathrm{C}$. After 90 minutes of equilibration, the aorta was contracted with $60 \mathrm{mM} \mathrm{KCl}$ solution to observe the aortic contractile muscle response, then rinsed with Krebs-Henselheit solution three times every 15 minutes. After the tone reached basal, the contraction response was tested with PE $10^{-6} \mathrm{M}$ and META $10^{-5} \mathrm{M}$ to test the endothelial integrity. Aorta with endothelial-intak if after the administration of PE solution the contraction responses reached peak contraction at plateau (flat line), and then the administration of META solution induced vasorelaxation response $>60 \%$. After the contraction response and endothelial integrity testing, the aorta was rinsed with Krebs-Henselheit solution three times every 15 minutes until the tones returned to basal and it was ready for aortic bioassay test with the endothelium-intak.

\section{Aorta with Endothelium Bioassay}

The aorta was contracted with PE $10^{-6} \mathrm{M}$, after reaching peak contraction at plateau CFS methanol extract or Control (the solvent) was administered with cumulatively and logarithmically increasing concentrations $\left(10^{-2}\right.$ to $\left.10^{1} \mathrm{M}\right)$ at 100 -second intervals. The solvent used to dissolve the extract and also used as a control was as described by Ismail and Kosala [12]. The presence of decreased aortic tone after extract or Control administration signifies a vasorelaxation response; increased aortic tone signifies a vasoconstriction response. The results are expressed in percent vasorelaxation. The method to calculate percent vasorelaxation effect was as described by Ismail and Kosala [12]. Repetition is accomplished by using five rats. 


\section{Aorta with Endothelium-denuded Bioassay}

The aorta's endothelial was mechanically removed by passing the aorta through a stainless wire while being rubbed. Aorta was said to have its endothelium-denuded if the vasodilation activity is $<10 \%$ after it was contracted with PE solution $\left(10^{-6} \mathrm{M}\right)$ and after META $\left(10^{-2} \mathrm{M}\right)$ solution was given when the peak contraction response at plateau was reached. Subsequent tests were similar as to those in the aorta with endothelium bioassay.

\section{Data analysis}

Data is presented in mean \pm SEM. Vasorelaxation activity is expressed in the concentration-response curve which is tabulated in the following graph created using Sigma Plot ver. 12 program. T-test with Sigma Plot ver. 12 was used for the statistical test, significantly different if $p<0.05$.

\section{RESULT AND DISCUSSION}

The result of bioassays on the isolated aorta with endothelium can be seen in Figure $A$, the aortic vasorelaxation activity is increasing in both the control group and in the CFS extract group as the concentration of Control and CFS extract put into the chamber increased. The vasorelaxation activity of CFS extract is greater than Control. This shows that a solvent containing 10\% DMSO-ethanol at high concentrations can cause a little vasorelaxation activity in the aortic blood vessels with endothelium. The results on the Control group differed from the previous studies where the solvents containing 10\% DMSO-ethanol caused slight contraction in the rat's isolated aorta with endothelium [11-13]. This may be due to the large amount of solvent extract in this study, reaching $300 \mu \mathrm{L}$ at the end of the study resulting in some vasorelaxation responses, whereas in the previous study it was only about $100 \mu \mathrm{L}$.

We have known that vasorelaxation and vasoconstriction in blood vessels can be mediated by endothelial and VSMC. Endothelium causes vasorelaxation of blood vessels mediated by nitric oxide (NO) via soluble guanylate cyclase (sGC), prostacyclin (PGI2) via IP receptors in VSMC and endothelium-derived-hyperpolarizing-

factor (EDHF) which results in hyperpolarization in VSMC resulting in the closure of calcium ion channels in VSMC causing the concentration of calcium ions in the cytosol to decrease (Sandoo et al., 2010). Endothelium may also play a role in vasoconstriction mediated by thromboxane (TXA2) and endothelin-1 (ET-1) [14]. Vasorelaxation also can be mediated by obstacles on the calcium ion channels in VSMC. Endothelial dysfunction or loss of endothelial normal function may have implications which disrupt vasodilation and increase blood pressure and it is also a part of the pathomechanism of hypertensive disease [15].

Bioassay results in the aorta with denuded endothelium can be seen in Figure B. In the CFS extract group, the aortic vasorelaxation activity is increasing as the administered extracts' concentration increased, as opposed to the Control group where the solvent can cause vasoconstriction in the aorta with endothelium-denuded. These results confirm that the previous studies on solvent administration on endotheliumdenuded can increase vasoconstriction of blood vessels [11-13].

Figure 1 shows that at low extract's concentrations, endothelial play a bigger role in vasorelaxation of blood vessels, but at high extracts' concentrations endothelium actually play 
a role in weakening VSMC-mediated vasodilation of blood vessel. This could happen because endothelium can release endothelium-derived contracting factors (EDCF) such as endothelin, prostaglandin $\mathrm{F}_{2 \alpha}$ and Tromboxan $\mathrm{A}_{2}$ [16]. Further research is needed to prove this by administering an inhibitor on these three components. The results of this study show that CFS extract in small concentrations can cause vasodilation of aortic blood vessels through endothelial and VSMC mediation. At high concentrations the vasorelaxation is primarily mediated by VSMC whereas the presence of endothelium actually weakens the vasodilation mediated by VSMC.

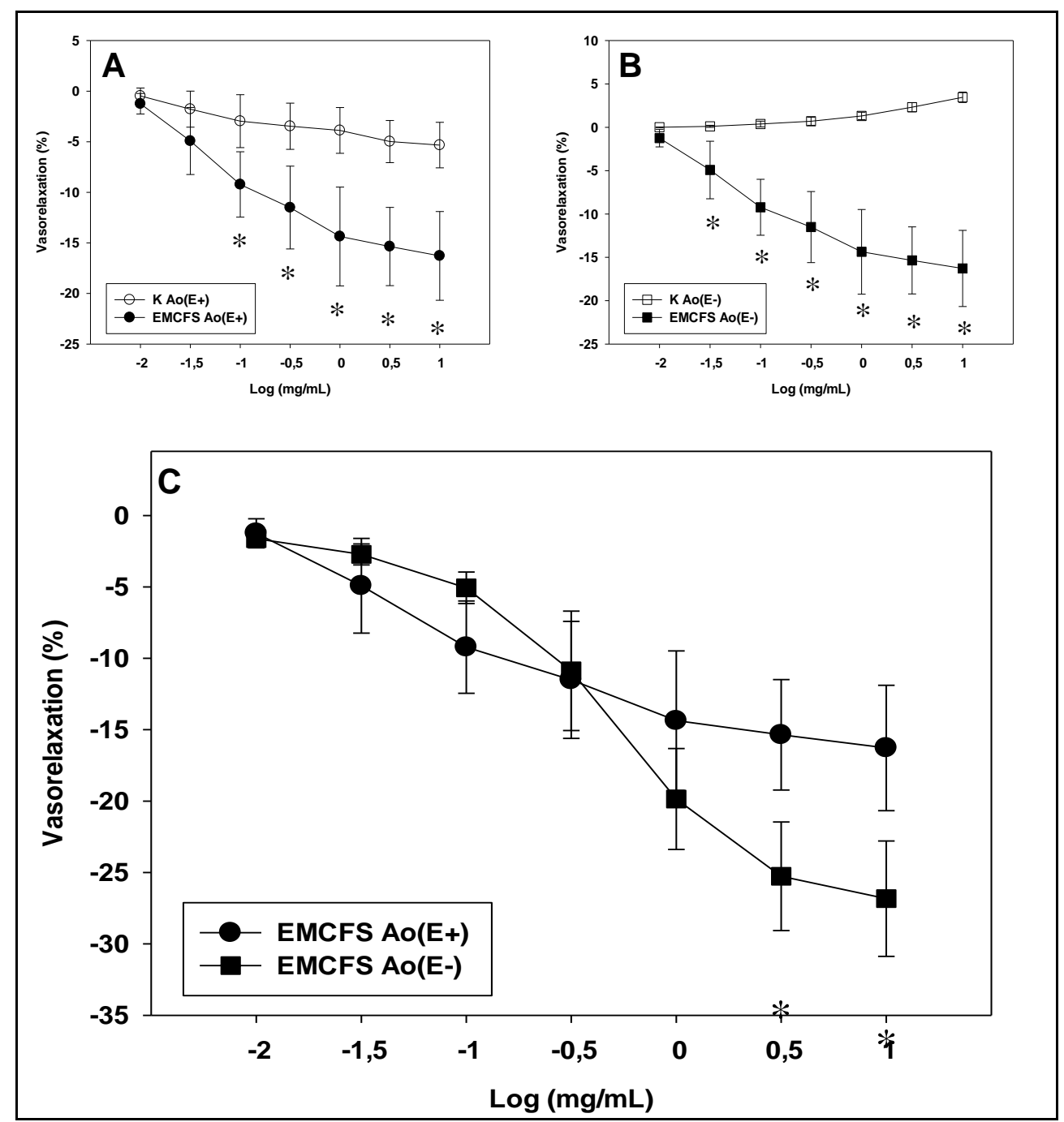

Figure 1. Vasorelaxation Response Curve of Rat Aortic Administered with Cumulative Log Concentration of Control and CFS Extract.

Note: $\mathrm{n}=5$, values are expressed as mean \pm SEM. Ao(E+)=Aorta with endothelium-intak, $\mathrm{Ao}(\mathrm{E}-)=$ Aorta with endothelium denuded, $\mathrm{K}=\mathrm{Control}$, EMCFS=extract methanol Coptosapelta flavescens Stems. *Denotes significant difference $t$-test compared at the level $p<0.05$. 
The anthraquinone and naphthoquinone isolates from CFS have been shown to have antigiardial and antientamoebal activity $[5,6,17]$. The derivate of both isolates from other plants has been shown to induce vasorelaxation of blood vessels [8,18]. Dantas et al. (2014) has proven that NaphthoquinoneOxime derivate from lapachol can cause endothelium-independent blood vessel relaxation, i.e. NO pathways by activating sGC [19]. Further studies on CFS extracts are needed to prove the endothelium-independent pathway via NO pathways by blocking sGC with methylene blue in isolated aorta with endothelium denuded.

\section{CONCLUSION}

Coptosapelta flavescens Stems' methanol extract showed in vitro vasorelaxation activity in both rat's aorta with endothelial-intak and endothelial denuded

\section{ACKNOWLEDGMENT}

The funding for this research came from the Year 2017 Financial Grant from Mulawarman University's Faculty of Medicine's Lecturer Research Competition.

\section{REFERENCES}

[1] Hajjar I, \& Kotchen TA. 2003. Trends in prevalence, awareness, treatment, and control of hypertension in the United States, 1988-2000. Journal of the American Medical Association, 290:199206.

[2] World Health Report. 2002. Reducing risks, promoting healthy life. Geneva, Switzerland: World Health Organization. 2002. Available at: http://www.who.int/whr/2002/. Acessed 10/23/2017.

[3] Darusman KL. 2004. Final technical report: The potential of medical plants to support sustainable forest management: ecological, economic, and sociocultural aspects. ITTO Pre-Project PPD 55/02 Rev. 2(I). Ministry of Forestry-Biopharmaca Research Center IPB-PT INHUTANI I. International Tropical Timber Organization, Bogor, Indonesia. Available at:

http://www.itto.int/files/itto_project_db in put/2766/Technical/PPD-55-02-R2-I-

Technical-Report.pdf. Acessed 10/23/2017.

[4] Rezeky FC. 2009. Fakultas MIPA Universitas Lambung Mangkurat, Banjarbaru, Indonesia. Skripsi (not published).

[5] Hounkong K, Sawangjaroen N, Kongyen W, Rukachaisirikul V, \& Voravunthikuncai SP. 2014. Antiintestinal protozoan activities of 1hydroxy-2-hyddroxymethylanthraquinone from Coptosapelta flavescens. Asian Pacific Journal of Tropical Disease, 4:457-465.

[6] Hounkong K, Sawangjaroen N, Kongyen W, Rukachaisirikul V, \& Wootipoom N. 2015. Mechanisms of 1-hydroxy-2hyddroxymethylanthraquinone from Coptosapelta flavescens as an antigiardiasis activity. Acta Tropica, 146:1116.

[7] Komura H, Mizukawa K, Minakata H, Huang H, Qin G, \& Xu R. 1983. New anthraquinones from Eleutherine americana. Chemical and Pharmaceutical Bulletin, 31(11):4206-08.

[8] Chung MI, Gan KH, Lin CN, Ko FN, \& Teng CM. 1993. Antiplatelet effects and vasorelaxing action of some constituents of Formosan plants. Journal of Natural Products, 56(6):929-34.

[9] Kosala, K, Ismail S, Fikriah I, \& Rahayu A. Eksplorasi aktivitas vasodilatasi ekstrak batang Coptosapelta flavescens Korth. secara in vitro. Program Book Seminar Nasional ke-53 Pokjanas TOI, Fakultas Kedokteran Universitas Islam Malang, 1112 Oktober 2017. Abstrak.

[10] Ismail S, Ali MM, \& Soeatmadji DW. 2013, Efek suplemen L-arginin subakut peroral pada kontraksi aorta tikus diabetes. Journal of Experimental Life Science, 3(2):54-64.

[11] Ismail S \& Yuniati. 2016. Aktivitas vasodilatasi pembuluh darah secara in vitro dan uji toksisitas akut minuman fungsional herbal Kaltim. Journal of Pharmaceutical Chemistry, 3(3):197-201. 
[12] Ismail S, \& Kosala K. 2011. In vitro comparison test of vasodilation activity on two types of yellow root plant of the menisperaceae. Jurnal Kimia Mulawarman, 8(2):102-104.

[13] Kosala K, \& Ismail S. 2008. Aktivitas Kontraktilitas aorta pada ekstrak daun Andrographis paniculata. The Journal of Indonesian Medical Plant, 1(1):20-24.

[14] Sandoo A, Zanten JJCSV, Metsios GS, Caroll D, \& Kitas GD. 2010. The endothelium and its role in regulating vascular tone. The Open Cardiovascular Medicine Journal, 4:302-12.

[15] Giles TD, Sander GE, Nossaman BD. \& Kadowitz PJ. 2012. Impaired vasodilation in the pathogenesis of hypertension: focus on nitric oxide, endothelial-derived hyperpolarizing factors, and prostaglandins. The Journal of Clinical Hypertension, 14:198-205.

[16] Jin X, Otonashi-Sastoh Y, Zamani Y, Koyama T, Sun P, Kitamura Y, \& Kawasaki H. 2010. Endothelial modulation of agonist-induced vasoconstriction in mesenteric microcirculation. The Pharmaceutical Society of Japan, 130(5):723-728.

[17] Kongyen W, Rukachaisirikul V, Phongpaichit S, Sawangjaroen N, Songsing P, \& Madardam H. 2014. Anthraquinone and naphthoquinone derivates from the root of Coptosapelta flavescens. Natural Product Communications, 9:219-220.

[19] Dantas BPV, Ribeiro TP, Assis VL, Furtado FF, Assis KS, Alves JS, Silva TMS, Camara CA, França-Silva MS, Veras RC, Medeiros IA, Alencar JL, \& Braga VA. 2014. Vasorelaxation induced by a new naphthoquinone-Oxime is mediated by NOsGC-cGMP pathway. Molecules, 19:977385.

[18] Huang H, Qin G, \& Xu. 1983. New antraquinones from Eleutherine americana. Chemical and Pharmaceutical Bulletin, 31(11):4206-08.

How to cited this article :

Ismail S, Kosala K, Fikriah I, Magdaleni AR. 2017. Mechanism of Vasorelaxation Induced by Coptosapelta flavescens Stems Extract in Rat Thoracic Aorta. J. Trop.Pharm. Chem. (4)2. 95-100 